\title{
AGRICULTURAL LAND MARKET IN SLOVAKIA UNDER THE NEW LAND ACQUISITION LAW
}

\author{
Dušan DRABIK ${ }^{1 *}$, Miroslava RAJČÁNIOVÁ2
}

\author{
Address: \\ ${ }^{1}$ Agricultural Economics and Rural Policy Group, Wageningen University, The Netherlands. \\ ${ }^{2}$ Slovak University of Agriculture in Nitra, Faculty of Economics and Management, Department of Economics, Tr.A.Hlinku 2, 949 76 Nitra, \\ Slovakia; \\ Corresponding Author, e-mail: Dusan.Drabik@wur.nl
}

\begin{abstract}
This paper discusses recent developments in the market for agricultural land in Slovakia related to the new law on land acquisition. The stated objective of this law is to protect agricultural land from non-agricultural use. We analyze landrelated data as reported by sellers in the newly established Registry of offers of agricultural land administered by the Ministry of Agriculture and Rural Development. Our results show that the regions with the most fertile soils are not the ones with the highest average land prices. Moreover, we show that the average regional prices are very sensitive to price outliers. For example, the average price for agricultural land in Slovakia is 27,200 EUR per hectare. However, this price falls down to 6,300 EUR per hectare if only observations with prices below 10,000 EUR per hectare are considered.
\end{abstract}

Keywords: agricultural land, prices, market, law, Slovakia JEL: Q11, Q15

\section{INTRODUCTION}

On May 1, 2014 a ten-year moratorium, negotiated during Slovakia's accession to the European Union, ended. During this period, foreigners were (officially) not allowed to buy agricultural land in Slovakia. Since the rented land in Slovakia represents as much as 90 percent of the total utilized agricultural area (Ciaian et al., 2012a), and because country's average farm land prices are considerably lower than in Western Europe (Ciaian et al., 2012b), Slovak farmers have feared the increase in demand for agricultural land after opening the land market in May 2014. Although, there are no official statistics how much agricultural land was purchased by foreigners before May 2014, some estimate it could be as much as 100,000 hectares (out of 1.9 million) (Vrbsky, 2014). As a result, the Slovak Agricultural and Food Chamber, in which most of farmers are members, initiated talks with the Slovak Ministry of Agriculture and Rural Development to find ways to legally inhibit the direct purchases of land by foreigners as well as by domestic persons whose primary business is not agriculture (e.g., real estate agencies, law firms, or investors).

Because of the importance of protection of agricultural land for Slovak farmers, at the end of April 2014 the Ministry quickly presented a draft proposal of a new law on acquisition of agricultural land that was to be discussed in the parliament. Although the proposal divided the parliamentary parties into supporters and opponents, it was finally passed on May 16, 2014, and it came into effect on June 1, 2014. (Out of 127 present members of the parliament, 150 in total, 79 were in favor, 36 against, and 12 abstained (NRSR, 2014)). However, some of the opponents of the law find it unconstitutional and thus had asked the Constitutional Court of the Slovak Republic to investigate the law. The Constitutional Court has not made any decision yet.

The seller has to comply with the new law whenever the land is offered to a farmer who operates outside the village where the parcel of land is. The convoluted bureaucratic process as detailed in the law thus implicitly favors farmers in a given village. The law only concerns arable land and permanent pastures located in the exterior of a village. Moreover, the area of land sold has to be at least 2,000 square meters (regardless of whether an entire parcel or a part of it is sold). In a nutshell, the law stipulates that a party that wants to sell agricultural land can do so without following the law, provided the land is sold to a farmer who operates in the same cadastral area where the parcel of land is located. If the owner wants to sell the land to someone else, he or she is obliged to first offer the land to farmers in neighboring villages and only if they are not interested, the land can be sold to any buyer (not necessarily working in agriculture) from the European Union. Lazikova and Bandlerova (2014) and Lazikova et al., (2014) provide a detailed discussion of exceptions to and nuances of the simplified sequence presented earlier.

An owner who wants to sell his or her agricultural land to someone outside of a given cadastral area, is obliged to announce it in the Registry of offers of 
agricultural land (the Registry, henceforth), administered by the Ministry of Agriculture and Rural Development. The Registry contains information on the location of the parcel; the type of land; the total area of the parcel; the area corresponding to the owner's share; the identification number of the ownership document, and the parcel number. Most importantly, however, the Registry contains the price required by the seller.

The information on the area of land offered and the corresponding prices are valuable pieces of information about the land market in Slovakia because this is for the first time that such data are publically available. For example, Buday and Cicova (2014) use land market prices (i.e., after the contract has been signed) and areas from surveys of selected cadastral offices in Slovakia; however, these data are not publically available. It should be stressed, however, that the prices from the Registry are not market prices as they only represent the supply side of the market. At the time of this writing it is not known how many parcels of land have actually been sold.

The objective of this paper is to provide insight into the current situation on the land market in Slovakia, especially with respect to the workings of the new law. In the next section, we present some characteristics of the agricultural land sale offers in Slovakia between June 1 and October 10, 2014. The final section provides some concluding remarks.

\section{OFFERS OF AGRICULTURAL LAND IN NUMBERS}

881 land sale offers were published in the Registry between June 1 and October 10, 2014 (the period we analyze in this paper). The occurrence of offers was initially slow (a few per week) but then took off, reaching 50-60 items in high traffic weeks. Importantly, the number of new offers does not correspond one-toone to the number of sellers; it is because a typical seller owns shares in many parcels, which results in multiple offers in the Registry under the same seller. Another interesting feature of the land sales offers is that a seller almost always offers land for the same price regardless of the location of a parcel.

In Table 1, we summarize information on the offered agricultural land during the analyzed period. We provide the summary for each of the eight Slovakia's regions (Banska Bystrica, Bratislava, Kosice, Nitra, Presov, Trencin, Trnava, and Zilina), as well as for the whole of Slovakia. In the upper panel of the table, we present the summary indicators for all available observations. In the second panel, we present a similar analysis, considering only the observations for which the price of agricultural land does not exceed one EUR per square meter (i.e., 10,000 EUR per hectare). We discuss this (arbitrary) threshold later.

The first column of Table 1 presents the distribution of the number of land parcels included in the Registry. Most parcels offered are in Banska Bystrica and Nitra regions. The second column presents the total area of land (in hectares) that the parcels cover. The third column gives the actual area of land offered for sale in individual districts. The values in the third column are generally smaller than in the second one because a parcel can have several co-owners and only some of them might sell the land. The fourth column presents the average parcel size (in hectares) for each of the regions as well as for Slovakia. This is a rough indicator of the degree of land fragmentation in individual regions. The data indicate that in our sample, Bratislava, Trencin, and Trnava regions have most fragmented land. The values in the fifth column proxy ownership fragmentation, albeit very roughly, assuming a uniform distribution of ownership shares for all parcels. Banska Bystrica, Kosice, and Trnava regions appear to face the biggest problem of ownership fragmentation.

Finally, the last column gives estimates of areaweighted average prices of agricultural land in individual regions and for the whole of Slovakia. In the upper panel, we consider all prices in the Registry. In that case, the land prices in Kosice and Presov regions are the highest, reaching 45,800 and 71,000 EUR per hectare, respectively. This is surprising as these prices are significantly higher than in Bratislava (35,000 EUR per hectare) or Trnava $(4,200$ EUR per hectare) regions in which there are Slovakia's most fertile soils and the economic activity is also higher than in other regions. Clearly, the price results in the upper panel of Table 1 are affected by extreme land prices. For example, some land in the district of Vranov nad Toplou (Presov region) is being sold at 50,000 EUR per hectare. Such a price is highly unlikely to be representative of the value of agricultural land in that region, and might rather reflect some future development expectations of the seller.

To see how the extreme values affect the areaweighted average land prices in individual regions, in the lower panel of Table 1 we consider only the observations for which the land price is not greater than one EUR per square meter. While this is an arbitrary threshold, it reflects an empirical observation before June 1, 2014 when the most fertile lands in the south-west of Slovakia were not sold for more than 10,000 EUR per hectare. The exclusion of the price outliers significantly changes average prices in all regions. The lowest land price appears to be in Banska Bystrica region, while the highest price is now in Nitra region. Interestingly, the most productive region of Trnava, exhibits the third lowest price.

Using the data from the Registry, in Figure 1 we present an empirical estimate of the cumulative distribution of land sales for Slovakia. The black solid line is constructed using all prices and corresponding areas while the red dashed line only considers the observations where the required price per square meter of land is no more than one EUR. The key feature of Figure 1 is that neither curve is similar to the textbook example of land supply curve. It is because the offered land constitutes only a small fraction of all agricultural land in the country. In Figure 1, we also do not control for characteristics of sellers, nor do we account for land quality and thus the land quantity represented on the horizontal axis is not homogeneous (we are grateful to an 
anonymous reviewer for pointing this out). The black curve suggests that most of agricultural land is offered at relatively low prices. The red dashed curve (whose prices are read off the right vertical axis) is a magnification of the black solid curve for the land prices below one EUR per square meter.

\section{CONCLUDING REMARKS}

In this paper, we have discussed some early observations from the Registry of offers of agricultural land in
Slovakia where as of June 1, 2014 sellers of land of more than 2,000 square meters are obliged to announce their offers. We have noted that the published prices cannot be considered market prices as it is not known whether a potential buyer has been found, and, more importantly, whether he or she would be willing to accept the required price. In any case, an increasing number of data on the agricultural land offers is very useful to analyze the developments in the Slovak land market as currently there is no publically available data source of land market prices.

Table 1. Descriptive characteristics of the offers of agricultural land in Slovakia

\begin{tabular}{|c|c|c|c|c|c|c|}
\hline Region & $\begin{array}{l}\text { Number } \\
\text { of parcels }\end{array}$ & $\begin{array}{l}\text { Total area } \\
\text { of parcels } \\
\text { (ha) }\end{array}$ & $\begin{array}{l}\text { Offered } \\
\text { area } \\
\text { (ha) }\end{array}$ & $\begin{array}{l}\text { Average } \\
\text { parcel size in } \\
\text { a region (ha) }\end{array}$ & $\begin{array}{l}\text { Offered } \\
\text { area/total area }\end{array}$ & $\begin{array}{l}\text { Area-weighted } \\
\text { price } \\
\text { (EUR/hectare) }\end{array}$ \\
\hline & \multicolumn{6}{|c|}{ All prices } \\
\hline Banska Bystrica & 321 & 703 & 67 & 2.2 & 0.10 & 4,353 \\
\hline Bratislava & 14 & 8 & 8 & 0.6 & 0.90 & 34,954 \\
\hline Kosice & 159 & 936 & 203 & 5.9 & 0.22 & 45,774 \\
\hline Nitra & 201 & 403 & 304 & 2.0 & 0.75 & 9,969 \\
\hline Presov & 67 & 160 & 87 & 2.4 & 0.54 & 70,754 \\
\hline Trencin & 17 & 16 & 8 & 1.0 & 0.51 & 7,451 \\
\hline Trnava & 95 & 95 & 23 & 1.0 & 0.24 & 4,191 \\
\hline Zilina & 7 & 17 & 17 & 2.4 & 1.00 & 6,079 \\
\hline \multirow[t]{2}{*}{ Slovakia } & 881 & 2,338 & 716 & 2.7 & 0.31 & 27,204 \\
\hline & \multicolumn{6}{|c|}{ Prices not higher than $1 \mathrm{EUR} / \mathrm{m}^{2}$} \\
\hline Banska Bystrica & 315 & 697 & 62 & 2.2 & 0.09 & 3,372 \\
\hline Bratislava & 1 & 0 & 0 & 0.5 & 1.00 & 5,500 \\
\hline Kosice & 145 & 912 & 186 & 6.3 & 0.20 & 5,839 \\
\hline Nitra & 179 & 351 & 256 & 2.0 & 0.73 & 7,769 \\
\hline Presov & 42 & 74 & 34 & 1.8 & 0.46 & 5,412 \\
\hline Trencin & 8 & 12 & 6 & 1.5 & 0.52 & 3,708 \\
\hline Trnava & 60 & 65 & 16 & 1.1 & 0.25 & 4,213 \\
\hline Zilina & 5 & 16 & 16 & 3.2 & 1.00 & 4,722 \\
\hline Slovakia & 755 & 2,128 & 576 & 2.8 & 0.27 & 6,307 \\
\hline
\end{tabular}

Note: The values in the table correspond to a situation as of October 10, 2014.

Source: Authors' calculations.

Figure 1. Cumulative distribution of land sales in Slovakia

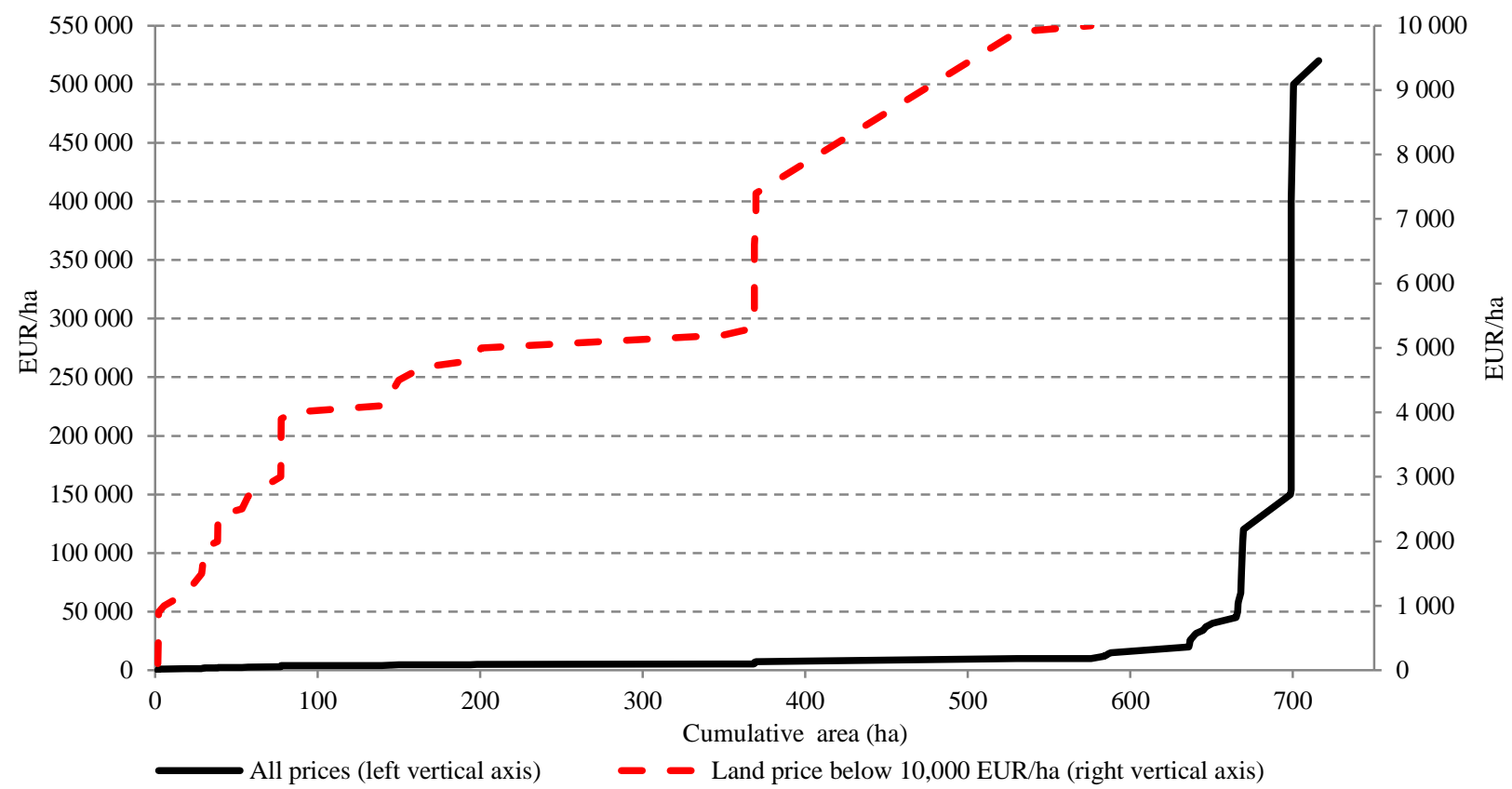

Source: Compiled by authors, based on data available at https://pozemky.mpsr.sk/ as of October 10, 2014. 
Our results show that the regions with the most fertile soils are not the ones with the highest average land prices. Moreover, we show that the average regional prices are very sensitive to price outliers. For example, the average price for agricultural land in Slovakia is 27,200 EUR per hectare. However, this price falls down to 6,300 EUR per hectare if only observations with prices below 10,000 EUR per hectare are considered.

Caution should be taken when making general conclusions out of the results presented in this paper. Apart from representing only the supply side, our results likely hide a lot of cadastral area-specific heterogeneity because of the regional aggregation we used. Moreover, because not all of the land that is actually sold has to be reported in the Registry, our price results are probably biased downwards, especially if parcels of agricultural land smaller than 2,000 square meters are in the interior of a village or in the exterior with a potential of future construction development. Further, because of loopholes in the law (Lazikova et al. 2014), a lot of land transactions might not be reported in the Registry.

Future research should focus also on the demand side of the agricultural land market in Slovakia in order to analyze the market prices of agricultural land in the country.

Acknowledgments: The authors would like to thank two anonymous reviewers and the editor of this journal for their constructive comments and suggestions.

This work was co-funded by European Community under project no 6220220180: Building Research Centre “AgroBioTech”.

\section{REFERENCES}

BUDAY, S.- CICOVA, T. (2014). The Transactions on the Agricultural Land Market in Slovakia.” Agricultural Economics - Czech (forthcoming).

CIAIAN, P. - KANCS, D. - SWINNEN, J. - VAN HERCK, K. - VRANKEN, L. (2012a). Rental Market Regulations for Agricultural Land in EU Member States and Candidate Countries. Factor Markets. Working paper No. 15, February. http://www.factormarkets.eu/system/files/FM WP15\%20 CEPS\%20on\%20Rental\%20Market\%20Regulations.pdf CIAIAN, P. - KANCS, D. - SWINNEN, J. - VAN HERCK, K. - VRANKEN, L. (2012b). Key Issues and Developments in Farmland Sales Markets in the EU Member States and Candidate Countries. Factor Markets. Working paper No. 12, February.

http://www.ceps.be/book/key-issues-and-developmentsfarmland-sales-markets-eu-member-states-and-candidatecountries

LAZIKOVA, J. - BANDLEROVA, A. (2014). "Acquisition of the Property Rights to the Agricultural Land in Slovakia.” A paper presented at a conference entitled Challenges and Perspectives of Agrarian Law. May 19-20, 2014, Nitra, Slovakia.

LAZIKOVA, J. - TAKAC, I. - SCHWARCZ, P. BANDLEROVA, A. (2014). Agricultural Land Market in Slovakia - Economic and Legal Impacts of the Law no. 140/2014 Coll. on the Land Acquisition. Working paper. Faculty of European Studies and Regional Development, Slovak University of Agriculture, Nitra NRSR (National Council of the Slovak Republic) (2014). https://www.nrsr.sk/web/Default.aspx?sid=schodze/hlaso vanie/hlasklub\&ID=33905

VRBSKY, K. (2014). Nový zákon o pôde prebudil vášne aj na Agrokomplexe. 26.08.2014. http://www.polnoinfo.sk/clanok/3789/novy-zakon-opode-prebudil-vasne-aj-na-agrokomplexe 